\title{
POLA SPASIAL BAHAYA GEMPA BUMI DI SEKITAR BANDARA KERTAJATI DAN KESESUAIANNYA TERHADAP TATA RUANG WILAYAH
}

\author{
Suliyanti Pakpahan ${ }^{1,2, *}$, Mangapul P. Tambunan ${ }^{1}$, Masita Dwi Mandini Mannesa ${ }^{1}$, Rudy P.Tambunan ${ }^{1}$ \\ ${ }^{1}$ Departemen Geografi, Fakultas MIPA, Universitas Indonesia \\ ${ }^{2}$ Badan Meteorologi, Klimatologi, dan Geofisika \\ *Penulis Korespondensi : suliyanti.p@ui.ac.id
}

\begin{abstract}
Abstrak. Gempa bumi tercatat sebagai bencana alam paling merusak. Kerusakan dapat ditekan jika pembangunan mempertimbangkan zonasi bahaya gempa setiap wilayah. Kawasan di sekitar Bandar Udara Internasional Jawa Barat Kertajati, yang dekat dengan beberapa sumber gempa, berpotensi berkembang pesat seiring beroperasinya bandara serta pembangunan infrastruktur pendukungnya. Penelitian bertujuan menganalisis pola spasial bahaya gempa bumi di 3 (tiga) kecamatan sekitar BJIB, yaitu Kecamatan Kertajati, Ligung, dan Jatitujuh sebagai upaya pengendalian dan pengurangan risiko bencana. Dengan metode AHP berbasis Sistem Informasi Geografis, dilakukan tumpang susun parameter efek tapak lokal, geologi, dan seismotektonik untuk membangun peta bahaya gempa bumi. Kesesuaian tata ruang diperoleh dari analisis tumpang susun peta bahaya gempa bumi dengan peta pola ruang dalam RTRW Kabupaten Majalengka. Hasil penelitian menunjukkan kawasan BJIB berada di zona bahaya gempa bumi sedang, diapit zona bahaya tinggi di bagian selatan dan bahaya rendah di utara. Pengembangan BJIB Kertajati direkomendasikan dilakukan ke arah utara yang relatif lebih stabil terhadap guncangan gempa bumi. Evaluasi pola ruang terhadap peta bahaya gempa bumi menunjukkan perencanaan wilayah di sekitar BJIB Kertajati oleh Pemerintah Kabupaten Majalengka sudah cukup baik, hanya 5,8\% area penelitian yang berada di zona bahaya gempa bumi tinggi.
\end{abstract}

Kata Kunci: AHP; bahaya; BJIB Kertajati; gempa bumi; pola ruang

\begin{abstract}
Earthquakes are listed as the most destructive natural disasters. It can be reduced if the regional development considers earthquake hazard zonation. The area around Kertajati International Airport, which is close to several earthquake sources, will develop rapidly along with the opening of the airport and the development of supporting infrastructure. This study aims to conduct a spatial analysis of earthquake hazard in 3 (three) sub-districts around BJIB, namely Kertajati, Ligung, and Jati Tujuh as an effort to controll and reduce earthquake risk. Using the AHP method based on the Geographic Information System, local site effect, geology, and seismotectonic parameters were overlayed to build a map of earthquake hazard. Spatial suitability was obtained from the analysis of overlapping earthquake hazard maps with the Spatial Pattern map of the Majalengka Regency RTRW. The results showed that the BJIB area is in a moderate hazard zone, flanked by a high hazard zone in the south and a low hazard zone in the north. It is recommends that the development of the Kertajati BJIB should be carried out to the north (low hazard zone). Spatial Planning evaluation based on earthquake hazard map shows that the regional planning around BJIB Kertajati by the Majalengka Government is quite good, only $5.8 \%$ of the area is in the high earthquakeprone zone.
\end{abstract}

Keywords: AHP; hazard; BJIB Kertajati; earthquake; spatial

\section{PENDAHULUAN}

Gempa bumi tercatat sebagai salah satu bencana alam yang paling berbahaya dan merusak (Tehseen dkk., 2020). Di Indonesia, gempa bumi menimbulkan kerusakan dan kerugian paling besar diantara bencana alam lain seperti banjir, tanah longsor, kebakaran hutan, puting beliung, dan lainlain. Sepanjang tahun 2000 hingga 2016, bencana gempa bumi tercatat mengakibatkan kerugian terbesar senilai $\mathrm{Rp}$ 7,56 triliun (Kementerian Keuangan Republik Indonesia, 2019), lihat Tabel 1. Dengan persentase kejadian kurang dari $1 \%$ dari total 18.777 bencana yang terjadi, gempa bumi menelan korban jiwa paling banyak setelah tsunami.

Gempa bumi tidak dapat dihindari, namun dampak kerusakan dan korban jiwa dapat ditekan. Kerusakan akibat gempa bumi sangat dipengaruhi oleh efek tapak lokal (local site effect) sebagai respon 
karakteristik tanah terhadap gelombang seismik (Kumar dkk., 2016). Gempa bumi Chamoli berkekuatan Mw6.8 di India tahun 1999 mengakibatkan kerusakan terbesar di Delhi dan Dehradun yang berjarak sekitar $200 \mathrm{~km}$ dari pusat gempa (Kumar dkk., 2016). Gempa bumi Bantul di Yogyakarta 27 Mei 2006, kerusakan paling parah terkonsentrasi di zona Graben Bantul yang relatif jauh dari pusat gempa, sedangkan daerah dekat sumber hanya mengalami kerusakan ringan (Daryono dkk., 2018). Pemetaan efek tapak lokal di Kota Padang menunjukkan kesesuaian peta dengan kerusakan akibat gempa Padang tahun 2009 di mana kerusakan terberat terjadi di zona kerentanan amplifikasi tinggi dan sangat tinggi (Tohari dan Wardhana, 2018).

Perencanaan wilayah yang baik merupakan mekanisme kunci untuk pengurangan risiko bencana (León dan March, 2017). Pengurangan risiko bencana terbagi atas 4 (empat) tahap yang saling berkaitan, yaitu mitigasi, kesiapsiagaan, tanggap darurat, dan pemulihan (BNPB, 2008; León dan March, 2017). Penataan ruang sebagai tahap pertama mitigasi untuk pengurangan potensi atau konsekuensi jangka panjang dari suatu bencana (León dan March, 2017). Namun masih sangat jarang evaluasi RTRW berbasis bencana gempa bumi. Satu diantaranya adalah analisis RTRW Kota Sabang berdasarkan jalur patahan aktif (Sjafrizal dkk., 2017). Hasil penelitian menunjukkan RTRW belum mengacu aturan pengurangan risiko bencana karena sebagian besar berada pada jalur patahan aktif.

Kabupaten Majalengka cukup rentan bencana geologi dan memiliki risiko tinggi terhadap bencana gempa bumi (BNPB, 2020). Tercatat 2 (dua) gempa bumi merusak pernah terjadi di wilayah ini, yaitu gemba bumi berkekuatan M 5.8 pada 6 Juli 1990 dan M 5.3 pada 28 Juni 2001 (BMKG, 2018). Sesar naik Baribis memanjang dari Majalengka hingga ke Subang cukup aktif dan menjadi sumber kegempaan di daerah ini (Pusat Studi Gempa Nasional, 2017).

Bandar Udara Internasional Jawa Barat (BIJB) Kertajati di Kabupaten Majalengka merupakan nomor dua paling besar di Indonesia setelah Bandar Udara Soekarno-Hatta (Rochman dkk., 2021). Beroperasi sejak 8 Juni 2018, proses pengembangan bandara diiringi pembangunan aerocity sebagai penyangga BJIB yang proses pembangunannya berjalan hingga 2045 mendatang (Rochman dkk., 2021). Hal ini akan menjadikan wilayah di sekitar bandara sebagai pusat pertumbuhan baru, khususnya Kecamatan Kertajati, Jatitujuh, dan Ligung.

Penataan ruang merupakan bagian dari upaya mengurangi risiko bencana (Presiden Republik Indonesia, 2007a, 2007b). Untuk itu, penelitian ini bertujuan menganalisis secara spasial tingkat bahaya gempa bumi dan mengevaluasi pola ruang di Kecamatan Kertajati, Ligung, dan Jatitujuh dalam upaya pengendalian dan mitigasi risiko bencana.

Tabel 1. Bencana alam di Indonesia periode 2000-2016 (BNPB, n.d.; Kementerian Keuangan, 2019)

\begin{tabular}{cccc}
\hline Jenis Bencana Alam & Jumlah Kejadian & Kerugian (Rp. Miliar) & $\begin{array}{c}\text { Meninggal } \\
\text { \& Hilang }\end{array}$ \\
\hline Banjir & 7.394 & 4.640 & 4.724 \\
Tanah Longsor & 3.804 & 1.290 & 2.661 \\
Gelombang Pasang/Abrasi & 277 & 50 & 81 \\
Putting Beliung & 4.625 & 50 & 379 \\
Kekeringan & 1.852 & 10 & 2 \\
Karhutla & 507 & 5.320 & 39 \\
Gempa Bumi & 219 & 7.560 & 8.739 \\
Tsunami & 12 & 2.710 & 167.143 \\
Letusan Gunung Api & 86 & 1.250 & 438 \\
Perubahan Iklim & 1 & 95 & 95 \\
Jumlah & 18.777 & 22.975 & 184.301 \\
\hline
\end{tabular}




\section{METODOLOGI}

Pandemi Corona Virus Desease 2019 (COVID-19) di Indonesia berdampak pada pembatasan aktivitas masyarakat untuk menekan penyebaran virus (Menteri Dalam Negeri Republik Indonesia, 2021; Presiden Republik Indonesia, 2020). Pengambilan data primer sulit dilakukan sehingga digunakan data sekunder dari sumber resmi yang terkait. Nilai Vs30 diperoleh dari United States Geological Survey (USGS), nilai percepatan tanah puncak PGA (Peak Ground Acceleration) di batuan dasar untuk probabilitas terlampaui $10 \%$ dalam 50 tahun dengan grid 0,93 × 0,93 km dari Kementerian Pekerjaan Umum, peta RBI Kabupaten Majalengka dari Badan Informasi Geospasial (BIG), data geologi dari Peta Geologi Indonesia lembar Arjawinangun, serta pola ruang 3 Kecamatan dicuplik dari RTRW Kabupaten Majalengka Tahun 2011-2031.

Lokus penelitian adalah 3 (tiga) kecamatan yang berpotensi mengalami pertumbuhan paling pesat karena kedekatannya dengan BJIB Kertajati yaitu Kecamatan Kertajati, Kecamatan Jatitujuh, dan Kecamatan Ligung, lihat Gambar 1.

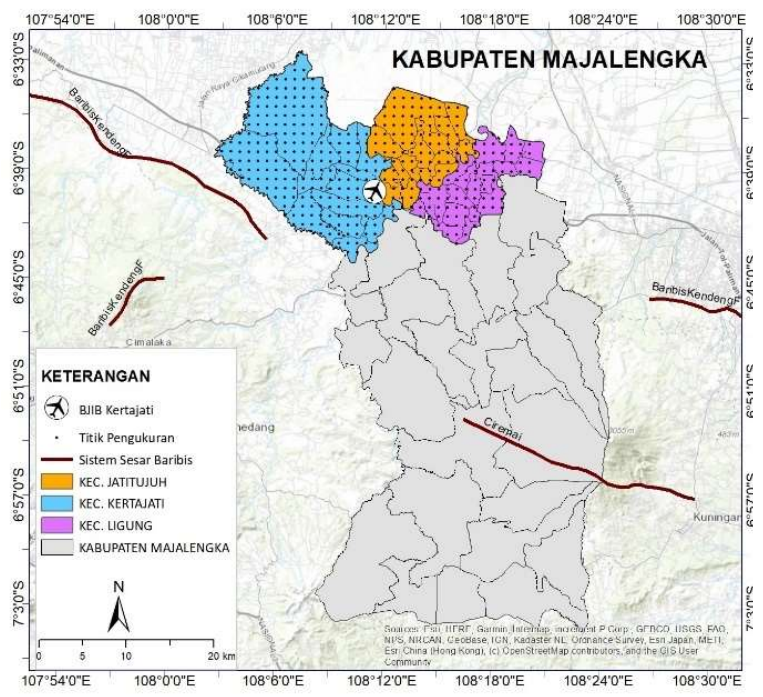

Gambar 1. Peta lokasi penelitian dan titik pengukuran

Peta bahaya gempa bumi disusun dari parameter efek tapak lokal yang diwakili oleh PGA permukaan, kondisi geologi, dan seismotektonik. Parameter kemiringan lereng tidak digunakan karena morfologi ketiga kecamatan relatif datar dengan kelerengan $<8$. Skoring pada setiap parameter didasarkan pada semakin berbahaya maka nilainya semakin tinggi (Bhatt dkk., 2019). Perbandingan berpasangan dengan Analytic Hierarchy Process (AHP) dilakukan untuk menghitung bobot setiap parameter. Evaluasi rencana pola ruang berbasis bahaya gempa bumi dengan tumpang susun pola ruang dan peta bahaya gempa bumi. Alur kerja penelitian ditampilkan pada Gambar 2.

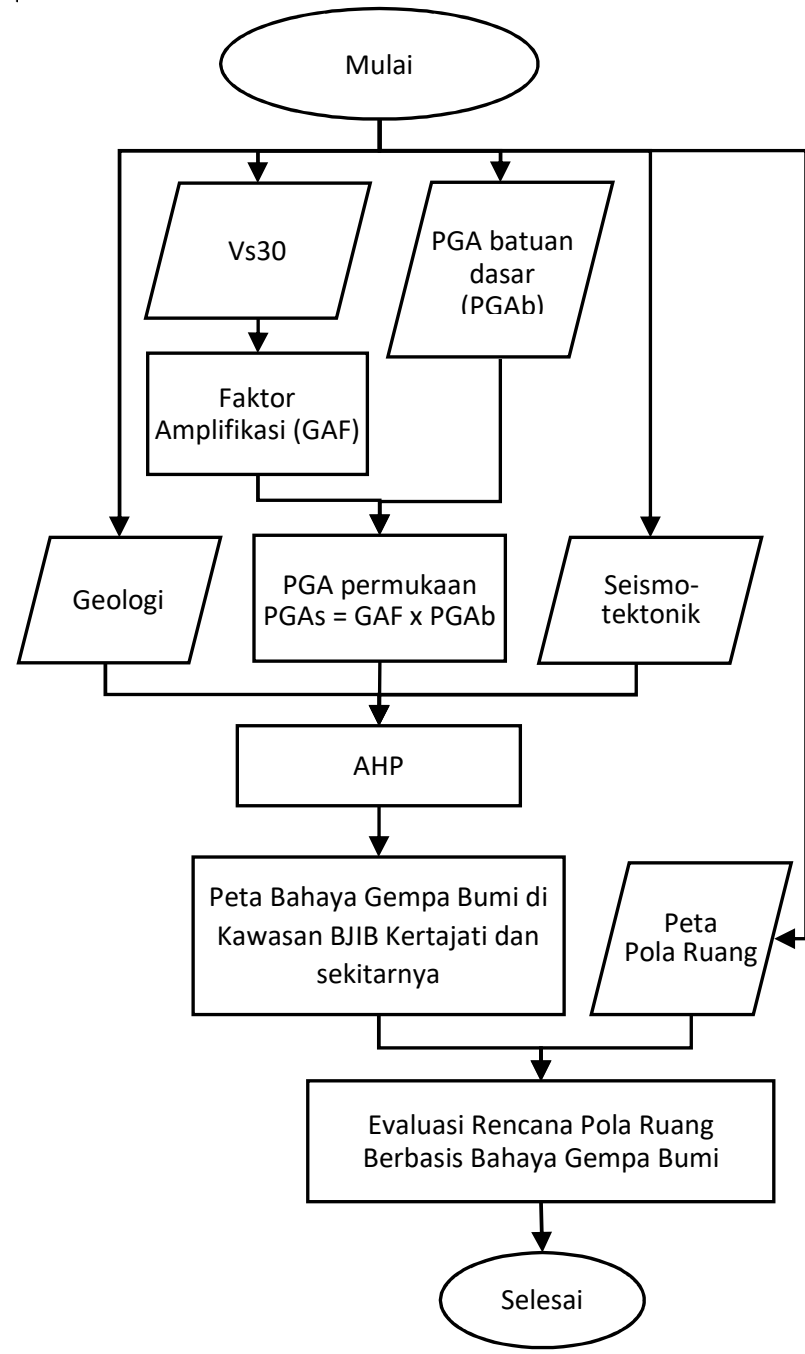

Gambar 2. Alur kerja penelitian

Midorikawa et al (1994) dalam BNPB (2015) merumuskan hubungan antara rata-rata kecepatan gelombang sekunder (shear wave) hingga kedalaman 30 meter (Vs30) dengan faktor amplifikasi tanah atau ground amplification factor $(\mathrm{G})$ sebagai berikut: $\log (G)=1,35-0,47 \log A V s 30 \pm 0,18$

Faktor amplifikasi terjadi karena adanya perbedaan kontras antara lapisan yang dilalui gelombang seismik, perbesaran gelombang terjadi saat gelombang gempa merambat melewati 
medium yang lebih lunak (Widyawarman dan Fauzi, 2020). Nilai faktor amplifikasi selanjutnya digunakan untuk menghitung nilai PGA di permukaan dengan Persamaan (2).

$P G A_{s}=G \times P G A_{b}$

dengan :

PGAs : nilai PGA di permukaan

PGAb : nilai PGA pada batuan dasar

Nilai PGA menggambarkan nilai maksimum percepatan tanah yang mungkin terjadi di suatu wilayah akibat gelombang gempa bumi (Yuliatmoko dkk., 2020). Semakin tinggi nilai PGA, semakin besar potensi guncangan terjadi.

Kondisi seismotektonik digambarkan sebagai jarak suatu daerah terhadap bidang patahan atau sesar yang menjadi salah satu dasar penilaian kestabilan suatu wilayah terhadap guncangan. Wilayah yang lebih jauh dari sesar akan lebih stabil karena semakin berkurangnya energi dari gempa yang bersumber dari bidang patahan (Bhatt dkk., 2019; Departemen Pekerjaan Umum Direktorat Jendral Penataan Ruang, 2007). Sumber gempa yang berada dekat dengan lokasi penelitian adalah Sistem Sesar Baribis yang memanjang dari Majalengka hingga ke Tangerang, dapat dilihat pada Gambar 3.

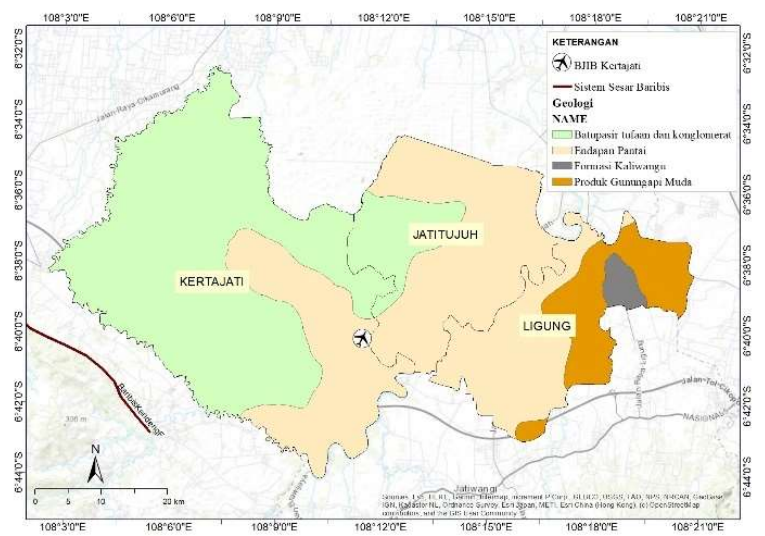

Gambar 3. Peta geologi dan seismotektonik di wilayah penelitian

Sistem sesar ini cukup aktif dan memicu beberapa gempa bumi, diantaranya gempa bumi berkekuatan M 3.1 pada 8 Februari 2018 dan M 2.6 pada 25 Juni 2019 di Kuningan dan Majalengka (Daryono, 2019). Berdasarkan jarak terhadap sumber gempa, Kecamatan Kertajati yang berada paling dekat dengan Sistem Sesar Baribis diberi skor paling tinggi, disusul Jatitujuh dan Ligung.

Berdasarkan peta geologi lembar Arjawinangun, kawasan BJIB dan sekitarnya didominasi oleh batuan sedimen, Gambar 3. Bagian barat dibentuk atas sedimen fluvial darat berupa batupasir dan konglomerat. Bagian tengah didominasi sedimen pantai, sedangkan bagian timur dibentuk oleh produk gunung api muda dan Formasi Kaliwangu yang terdiri dari batu lempung dan batuan halus. Jenis batuan yang lebih kompak akan lebih tahan terhadap guncangan gempa bumi serta lebih kecil kemungkinan mengalami longsoran mau pun amblasan. Berdasarkan klasifikasi Departemen Pekerjaan Umum Direktorat Jendral Penataan Ruang (2007), secara berurutan dari skor paling tinggi (batuan paling tidak kompak) hingga terendah (batuan lebih kompak), adalah Formasi Kaliwangu, endapan pantai, batu pasir tufaan dan konglomerat, serta produk gunung api muda.

Hasil studi pustaka dari beberapa sumber di atas menjadi acuan dalam penentuan skoring pada masing-masing parameter yang akan ditumpangsusun menjadi peta bahaya. Skoring masing-masing parameter dapat dilihat pada Tabel 2.

Tabel 2. Skoring tiap parameter untuk penyusunan peta bahaya gempa bumi

\begin{tabular}{ccc}
\hline Parameter & Variabel & Skor \\
\hline Geologi & $\begin{array}{c}\text { Formasi Kaliwangu } \\
\text { Endapan Pantai } \\
\text { Batupasir tufaan dan } \\
\text { konglomerat }\end{array}$ & 4 \\
& 2 \\
& Produk Gunungapi Muda & 1 \\
\hline Seismotektonik & Kertajati & 3 \\
(Jarak ke sumber & Jatitujuh & 2 \\
gempa) & Ligung & 1 \\
\hline Efek Tapak Lokal & $0,70-0,75 \mathrm{~g}$ & 5 \\
(PGA permukaan) & $0,65-0,70 \mathrm{~g}$ & 4 \\
& $0,60-0,65 \mathrm{~g}$ & 3 \\
& $0,55-0,60 \mathrm{~g}$ & 2 \\
& $0,50-0,55 \mathrm{~g}$ & 1 \\
\hline
\end{tabular}

Dengan metode AHP dilakukan perbandingan berpasangan untuk menghitung bobot masingmasing parameter. Bobot ditentukan berdasarkan kontribusi spesifik parameter tersebut terhadap bahaya gempa bumi di mana bobot yang lebih tinggi 
diberikan pada parameter yang berperan dalam bahaya gempa bumi (Bhatt dkk., 2019).

Kondisi seismotektonik lebih berpengaruh terhadap kerusakan yang terjadi dibandingkan kondisi geologi regional. Efek tapak lokal gempa bumi diberi bobot tertinggi, selanjutnya jarak ke sumber gempa, dan terakhir kondisi geologi. Diperoleh hasil pembobotan masing-masing 0,5 untuk PGA, 0,3333 untuk jarak sumber gempa, dan 0,1667 untuk kondisi geologi seperti ditunjukkan pada Tabel 3.

Tabel 3. Pembobotan tumpang susun dalam platform Sistem Informasi Geografis

\begin{tabular}{ccccc}
\hline Parameter & $\begin{array}{c}\text { Indeks } \\
\text { Bahaya }\end{array}$ & $\begin{array}{c}\text { Seismo- } \\
\text { tektonik }\end{array}$ & Geologi & Bobot \\
\hline PGA & 1 & $3 / 2$ & $3 / 1$ & 0,5 \\
Seismotektonik & $2 / 3$ & 1 & $2 / 1$ & 0,3333 \\
Geologi & $1 / 3$ & $1 / 2$ & 1 & 0,1667 \\
\hline Evaluasi & pola & ruang & dilakukan & untuk
\end{tabular}
mengetahui tingkat kesesuaian antara pola ruang dalam RTRW dengan potensi bencana gerakan tanah di ketiga kecamatan di sekitar BJIB Kertajati. Peta bahaya gempa bumi yang dihasilkan dijadikan dasar dalam mengevaluasi pola ruang di lokasi penelitian. Analisis kesesuaian pola ruang dilakukan dengan metode tumpangsusun (overlay) kedua data spasial yaitu peta rencana Pola Puang dan peta bahaya gempa bumi.

\section{HASIL DAN PEMBAHASAN}

\section{PGA, Vs30, dan Faktor Amplifikasi}

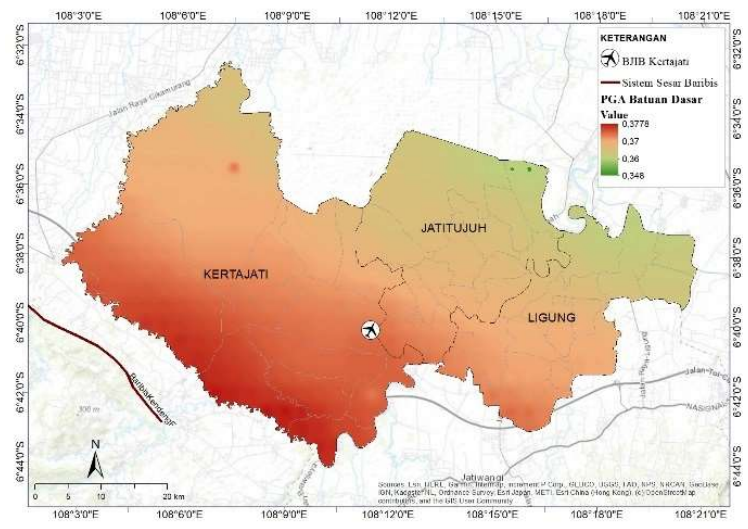

Gambar 4. Peta PGA di batuan dasar lokasi penelitian

Rentang nilai percepatan puncak tanah di batuan dasar di wilayah penelitian adalah 0,348 -
0,3778 gal dengan distribusi seperti pada Gambar 4 . Batuan dasar relatif homogen di bagian timur laut lebih kompak ditunjukkan dengan nilai PGA yang sedikit lebih tinggi dibanding lokasi lainnya.

Distribusi Nilai Vs30 di wilayah penelitian berkisar antara 180,625-309,728 m/det, lihat pada Gambar 5. Berdasarkan klasifikasi situs Badan Standarisasi Nasional, seluruh lokasi penelitian terbentuk atas jenis tanah sedang. Namun terdapat pola kelurusan dengan arah Timur Laut-Barat Daya yang ditunjukkan dengan nilai Vs30 sedikit lebih tinggi yang mengindikasikan lapisan batuan yang lebih padat (Susilanto dkk., 2019).

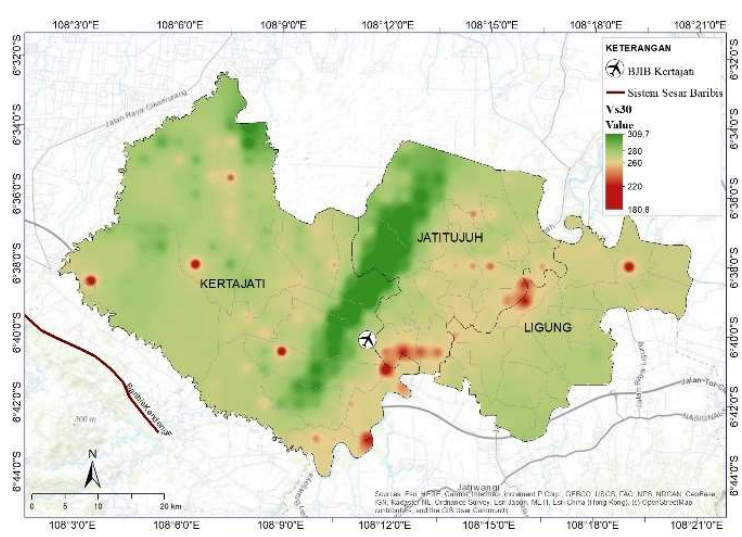

Gambar 5. Peta sebaran Vs30

Nilai faktor amplifikasi di wilayah penelitian berkisar antara 1,51 hingga 1,95 masuk kategori sangat rendah (Tohari dan Wardhana, 2018). Hal ini dapat dilihat Gambar 6. Nilai amplifikasi tinggi identik dengan lapisan tanah lunak dan berpotensi meningkatkan efek getaran sesimik akibat gempa bumi (Tohari dan Wardhana, 2018).

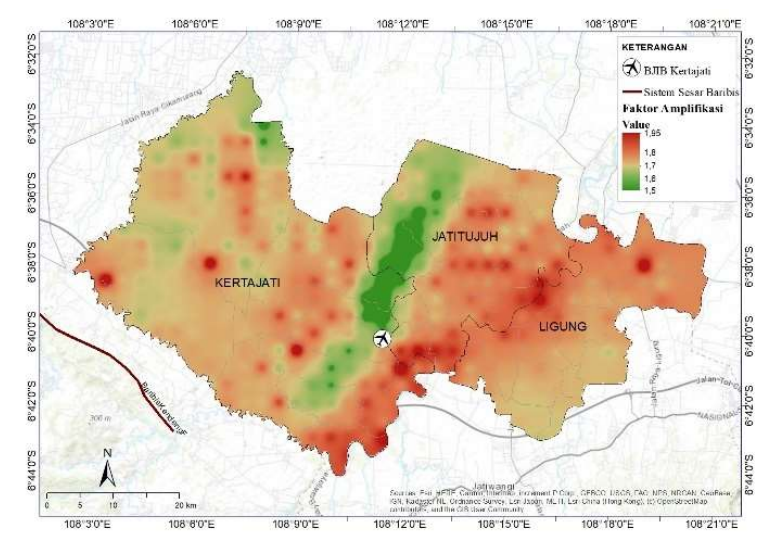

Gambar 6. Peta sebaran faktor amplifikasi 
Nilai amplifikasi memiliki korelasi terbalik dengan nilai Vs30. Kecepatan gelombang yang tinggi dan faktor amplifikasi yang lebih rendah menunjukkan tanah yang lebih kompak dan relatif lebih stabil dari guncangan gempa. Pada jenis tanah lunak yang dicirikan dengan rendahnya Vs30, gelombang akan mengalami amplifikasi yang lebih kuat (Susilanto dkk., 2019; Yuliatmoko dkk., 2020).

Distribusi Vs30 dan faktor amplifikasi pada Gambar 5 dan Gambar 6 menunjukkan pola yang seragam adanya nilai lapisan tanah yang lebih kompak di bagian tengah membujur berarah Timur Laut-Barat Daya. Tepatnya dari Desa Pilangsari dan Desa Babajurang (Kecamatan Jatitujuh) menerus ke Desa Paripis, Desa Bantarjati, hingga Desa Kertajati di Kecamatan Kertajati.

Percepatan puncak tanah permukaan di wilayah penelitian berada dalam kisaran $0,542-0,72 \mathrm{~m} /$ det dimana daerah dengan nilai tinggi terkonsentrasi di bagian selatan yaitu Desa Pasindangan dan Panongan di kecamatan Jatitujuh yang menerus ke selatan Kecamatan Kertajati di Desa Sukawana, Pakubeureum, dan desa-desa di dekatnya, lihat pada Gambar 7. PGA tinggi juga ditemui di beberapa titik Kecamatan Kertajati dan sebagian kecil Kecamatan Ligung. Kawasan BJIB Kertajati sendiri berada di daerah dengan percepatan tanah yang relatif tidak terlalu tinggi. Jika terjadi gempa, maka daerah dengan nilai PGA lebih tinggi akan mengalami guncangan lebih kuat dibanding daerah sekitarnya.

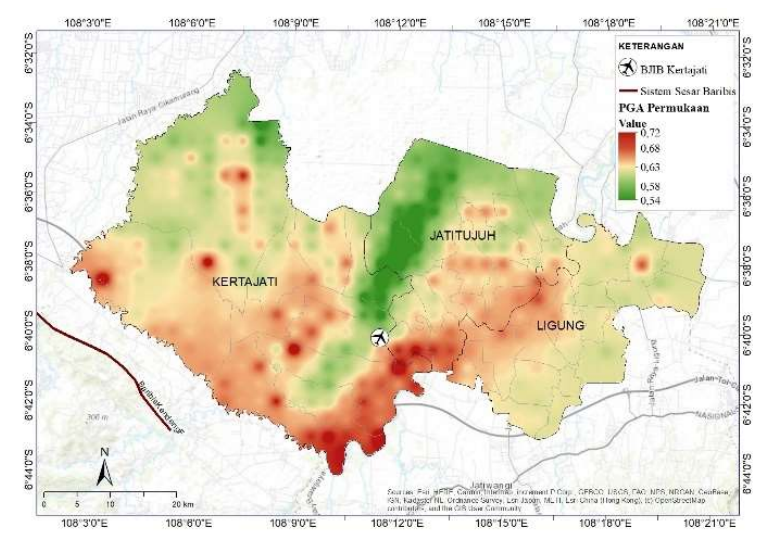

Gambar 7. Peta sebaran PGA permukaan

Selanjutnya penulis melakukan perhitungan indeks bahaya gempa bumi untuk memperoleh gambaran secara regional, bagaimana kelas bahaya gempa bumi daerah penelitian. Indeks bahaya diperoleh dengan reklasifikasi dan transformasi nilai intensitas guncangan di permukaan menjadi nilai indeks (Jati dan Amri, 2016). Nilai reklasifikasi kemudian diklasifikasikan kembali berdasarkan Indeks Bahaya Bencana Gempa Bumi yang diklasifikasikan oleh BNPB. Untuk PGA $<0,25$ masuk dalam klasifikasi rendah, lalu PGA di kisaran 0,25 0,70 masuk dalam kisaran sedang, sementara PGA > 0,70 masuk dalam klasifikasi ancaman tinggi (BNPB, 2015). Indeks bahaya gempa bumi di lokasi penelitian terdiri atas 0,875 dan 1 yang berarti ketiga kecamatan berada dalam satu kelas, indeks bahaya gempa bumi tinggi.

\section{Peta Bahaya Gempa Bumi}

Hasil tumpang susun parameter efek tapak lokal, geologi, dan seismotektonik menunjukkan daerah penelitian didominasi oleh zona bahaya gempa bumi rendah seluas $62,9 \%$, selanjutnya bahaya sedang $31,3 \%$, dan bahaya tinggi $5,8 \%$ dari luas wilayah, lihat Gambar 8. Zona bahaya tinggi terkonsentrasi di bagian selatan Kecamatan Kertajati, yaitu seluruh Desa Sukawana dan Pakubeureum, serta sebagian kecil wilayah Desa Babakan, Kertawinangun, Palasah, Kertajati, Bantarjati, dan Sukamulya.

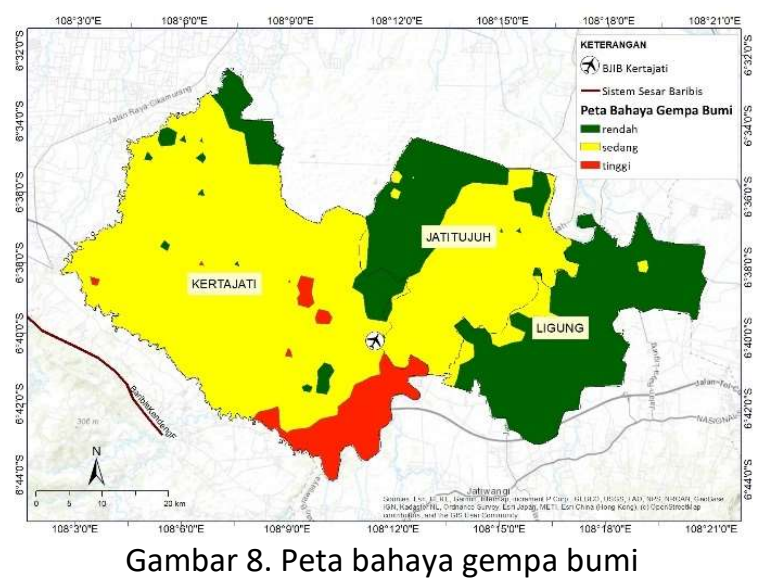

Hampir seluruh wilayah Kecamatan Ligung berada pada zona bahaya gempa dengan kategori rendah. Di Kecamatan Jatitujuh, zona bahaya rendah membujur dari utara hingga ke bagian barat daya, tepatnya di Desa Pilangsari dan Babajurang. Zona bahaya rendah juga ditemui di sebagian Desa Sumber Wetan. Hanya sebagian kecil wilayah 
Kecamatan Kertajati masuk kategori bahaya rendah, tersebar di beberapa lokasi yaitu Desa Paripis, Desa Babakan, dan Desa Mekarmulya. Wilayah penelitian didominasi oleh zona bahaya sedang, termasuk lokasi kawasan BIJB Kertajati. Lokasi bandara berada tepat di antara zonasi bahaya tinggi di bagian selatan dan bahaya rendah di bagian utara.

Beroperasinya Bandara Kertajati sejak 24 Mei 2018 lalu memicu percepatan pembangunan di wilayah sekitarnya. Diantaranya pembangunan jalan tol akses bandara mulai bulan September 2020 yang nantinya akan terintegrasi dengan Jalan Tol Cipali yang akan mempersingkat waktu dari Bandung menuju BJIB dari 3 jam menjadi 1 jam (Deny, 2020). Bandara juga akan terintegrasi dengan Pelabuhan Patimban di Subang Jawa Barat yang berjarak sekitar $40 \mathrm{~km}$.

Pembangunan infrastruktur bandara, juga aerocity sebagai pendukung, dan meningkatnya aksesibilitas akan mendorong petumbuhan wilayah dan perekonomian di sekitar BIJB Kertajati. Pemerintah daerah perlu menerapkan rencana pola ruang berbasis mitigasi bencana sejak dini. Berdasarkan peta bahaya gempa bumi yang dihasilkan, pengembangan pembangunan wilayah sebaiknya diarahkan ke utara bandara yang relatif lebih tidak rentan terhadap bahaya gempa bumi. Pengembangan tetap dapat dilakukan ke arah selatan, namun wajib menerapkan building code bangunan tahan gempa untuk menekan bahkan menghindari potensi kerusakan dan korban jiwa akibat gempa bumi.

Kedisiplinan dalam menerapkan building code terbukti dapat mengurangi bahkan menghidari jatuhnya korban jiwa seperti terjadi pada gempa bumi Alaska 30 November 2018. Gempa sangat kuat Mw 7.1 dengan kedalaman relatif dangkal 46,7 km hanya menyebabkan kerusakan ringan bangunan, serta kerusakan pada jalan raya dan jembatan (Alaska Seismic Hazards Safety Commission, 2018; D'Oro dan Thiessen, 2018). Tidak ada laporan kerusakan parah maupun korban jiwa akibat gempa karena kedisiplinan penerapan building code pada bangunan di wilayah tersebut.

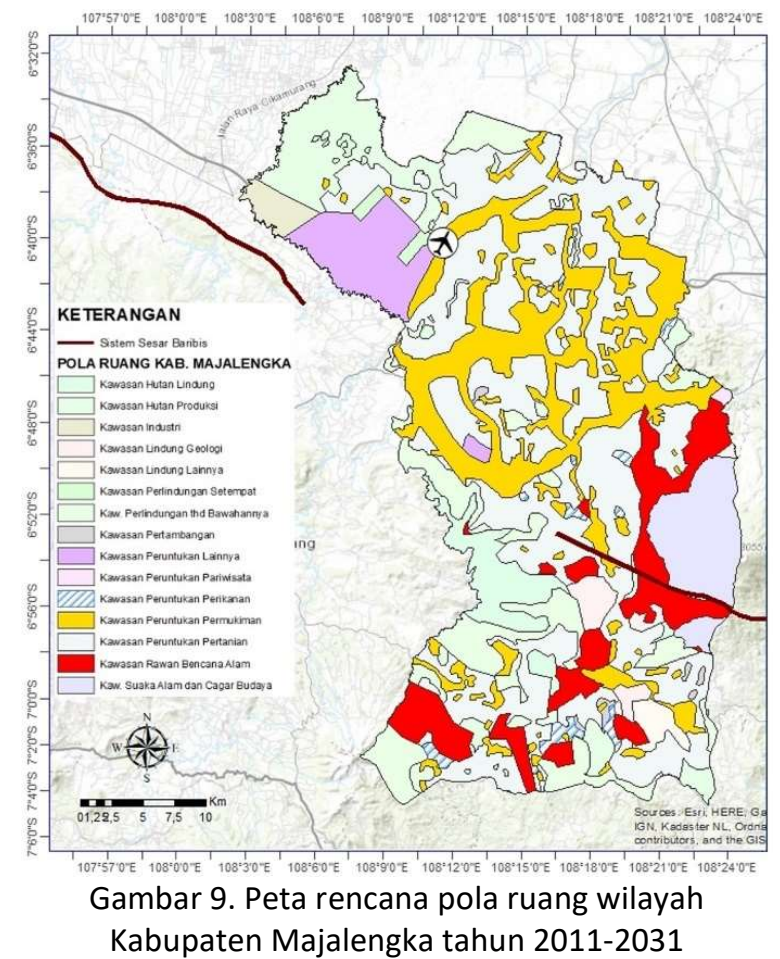

Sebagai perbandingan di Indonesia, Gempa Yogyakarta dengan kekuatan Mw 6,3 kedalaman 35 km menelan 6.234 korban jiwa meninggal dunia dan kerugian sekitar $\mathrm{Rp}$ 29,2 triliun (Ramadhan dan Wijaya, 2020). Lombok (Nusa Tenggara Barat) mengalami runtutan tiga gempa bumi besar dengan kekuatan M6.4 hingga M7.0 pada tanggal 29 Juli 2018, 5 Agustus 2018, dan 19 Agustus 2018 sebesar 6.9 SR yang mengakibatkan kerugian ekonomi mencapai Rp17,3 triliun dengan korban jiwa 421 orang meninggal dunia dan 1.412 korban luka-luka (Kementerian Keuangan Republik Indonesia, 2019; Kementerian Pekerjaan Umum dan Perumahan Rakyat, 2018; Ramadhan dan Wijaya, 2020).

\section{Evaluasi Kesesuaian Rencana Pola Ruang}

Perencanaan tata ruang harus peka terhadap ancaman risiko bencana untuk meningkatkan keselamatan dan kenyamanan kehidupan dan penghidupan di dalamnya (Presiden Republik Indonesia, 2007a). Perencanaan penataan ruang dalam Rencana Tata Ruang Wilayah (RTRW) selayaknya menjadi acuan dalam pengaturan, pengendalian, dan pemanfaatan ruang. Kabupaten Majalengka yang memiliki indeks bahaya gempa tinggi, harus menjadikan zonasi bahaya gempa 
sebagai dasar penataan ruang wilayahnya sebagai implementasi UU No. 26, 2007.

Pola ruang Kabupaten Majalengka tahun 20112031 terdiri atas 15 kawasan yang didominasi oleh kawasan peruntukan pertanian seluas 36,5\% dari total luas wilayah kabupaten Majalengka atau 489,3 $\mathrm{km}^{2}$, lihat Gambar 9. Kawasan peruntukan permukiman dialokasikan seluas $251,1 \mathrm{~km}^{2}$ atau $18,73 \%$ dari luas wilayah Kabupaten Majalengka. Kawasan rawan bencana alam berada di bagian selatan yang dilalui oleh Sistem Sesar Baribis segmen Ciremai.

Pada lokasi penelitian, yang terletak di bagian utara Kabupaten Majalengka, hanya terdapat tujuh fungsi kawasan dengan komposisi 92,4\% difungsikan sebagai kawasan budidaya dan $7,6 \%$ kawasan lindung. Persentase terbanyak $37,7 \%$ diperuntukkan sebagai kawasan pertanian. Hanya 13,6\% wilayah diperuntukkan bagi permukiman. Tumpang susun pola ruang dan peta bahaya gempa menunjukkan 5,8\% kawasan berada di zona bahaya tinggi, lihat Gambar 10. Kawasan ini antara lain peruntukan pertanian $10,75 \mathrm{~km}^{2}$; permukiman $3,94 \mathrm{~km}^{2}$; serta peruntukan lainnya seluas $5,26 \mathrm{~km}^{2}$.

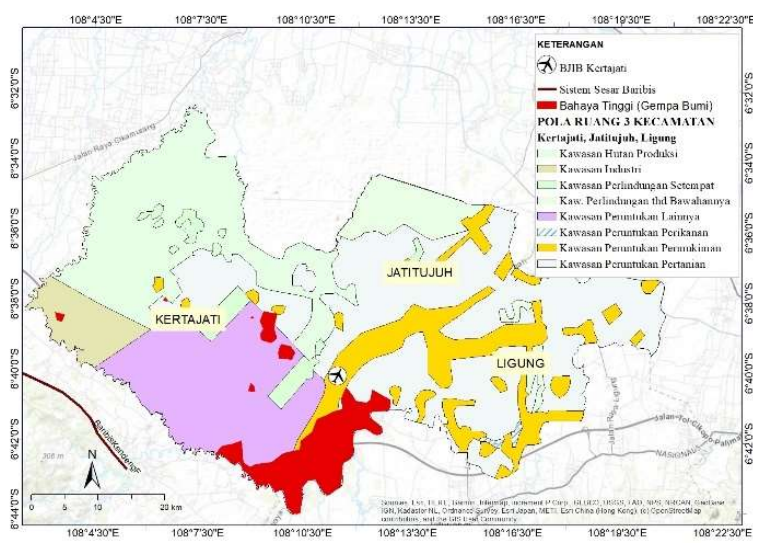

Gambar 10. Tumpang susun pola ruang dengan zona bahaya tinggi (merah)

Lokasi penelitian didominasi zona bahaya sedang dengan persentase $63,1 \%$ dari luas wilayah, diikuti zona bahaya rendah seluas $109,79 \mathrm{~km}^{2}$ atau $31,1 \%$ wilayah, lihat Tabel 4 . Hal ini menunjukkan secara keseluruhan perencanaan pola ruang yang dilakukan Pemerintah Kabupaten Majalengka sudah cukup baik, terlihat dengan minimnya kawasan budidaya khususnya permukiman dan industri di zona bahaya tinggi. Menjadi tugas pemerintah untuk mengawasi penerapan perencanaan pola ruang tersebut.

Tabel 4. Evaluasi pola ruang berbasis bahaya gempa

bumi di Kecamatan Kertajati, Jatitujuh, dan Ligung

\begin{tabular}{|c|c|c|c|c|}
\hline \multirow{2}{*}{ Fungsi Kawasan } & \multicolumn{3}{|c|}{ Zona Bahaya $\left(\mathrm{km}^{2}\right)$} & \multirow{2}{*}{$\begin{array}{l}\text { Total } \\
\left(\mathrm{km}^{2}\right)\end{array}$} \\
\hline & Rendah & Sedang & Tinggi & \\
\hline \multicolumn{5}{|l|}{ Kawasan Budidaya } \\
\hline Kaw. Hutan Produksi & 11,38 & 59,35 & 0,003 & 70,73 \\
\hline Kaw. Industri & - & 14,04 & 0,14 & 14,19 \\
\hline $\begin{array}{l}\text { Kaw. Peruntukan } \\
\text { Lainnya }\end{array}$ & 1,08 & 53,79 & 5,26 & 60,13 \\
\hline $\begin{array}{l}\text { Kaw. Peruntukan } \\
\text { Permukiman }\end{array}$ & 19,14 & 24,74 & 3,94 & 47,83 \\
\hline $\begin{array}{l}\text { Kaw. Peruntukan } \\
\text { Pertanian }\end{array}$ & 64,50 & 57,52 & 10,75 & 132,77 \\
\hline \multicolumn{5}{|l|}{ Kaw. Lindung } \\
\hline $\begin{array}{l}\text { Kaw. Perlindungan } \\
\text { Setempat }\end{array}$ & 0,12 & 9,54 & - & 9,66 \\
\hline $\begin{array}{l}\text { Kaw. Perlindungan } \\
\text { thd Bawahannya }\end{array}$ & 13,57 & 3,38 & 0,24 & 17,19 \\
\hline Persentase & 31,10 & 63,10 & 5,80 & 100,00 \\
\hline
\end{tabular}

\section{PENUTUP}

\section{Simpulan}

Peta bahaya gempa bumi hasil tumpang susun efek tapak lokal, seismotektonik, dan geologi menunjukkan wilayah Kecamatan Ligung lebih aman terhadap bahaya gempa bumi dibandingkan dengan dua kecamatan lainnya. Posisi BJIB Kertajati sendiri berada di area dengan Vs30 relatif tinggi dan PGA permukaan yang rendah menandakan bandara dibangun di batuan yang kompak. Posisinya diapit wilayah dengan zona bahaya rendah di sebelah utara dan zona bahaya tinggi di bagian selatan. Hal ini menunjukkan pengembangan wilayah ke arah utara akan lebih aman gempa, tepatnya ke Desa Paripis, Desa Babajurang, dan Desa Pilangsari. Pengembangan pembangunan ke arah selatan yang merupakan zona bahaya tinggi, seperti Desa Sukawana dan Pakubeureum, dapat dilakukan dengan penerapan regulasi kode bangunan (building code).

Pemerintah Daerah Kabupaten Majalengka sudah cukup baik dalam merencakan pola ruang di tiga kecamatan sekitar BJIB Kertajati di mana hanya $5,8 \%$ kawasan yang berada di zona bahaya gempa bumi tinggi. Pola ruang terhadap resiko bencana 
gempa bumi dikatakan sesuai jika tata guna lahan memiliki upaya untuk meminimalkan dampak kerusakan yang mungkin terjadi melalui regulasi pendirian bangunan yang aman dari gempa, penataan pemukiman dan bangunan, serta edukasi masyarakat akan tanggap bencana.

\section{Saran}

Metode pada penelitian ini dapat diterapkan untuk memetakan bahaya gempa bumi secara cepat di seluruh wilayah Indonesia, terlebih dengan pandemi yang membatasi pergerakan di tempat umum. Penelitian lebih lanjut dilakukan menggunakan data primer pengukuran mikrozonasi untuk memperoleh data lapangan yang lebih presisi mengukur efek tapak lokal.

Pemerintah harus tegas dalam mengontrol penerapan pola ruang wilayah di sekitar BJIB Kertajati tetap sesuai koridor RTRW yang telah ditetapkan. Sebagai wilayah dengan indeks bahaya gempa bumi tinggi, Pemerintah daerah perlu meningkatkan kapasitas penanggulangan bencana dalam rangka menekan potensi risiko dan dampak bencana gempa bumi.

\section{Ucapan Terima Kasih}

Ucapan terima kasih penulis haturkan kepada seluruh pihak yang telah membantu dalam penelitian ini, khususnya kepada Departemen Geografi Universitas Indonesia serta Pusat Penelitian dan Pengembangan BMKG. Tak lupa terima kasih kepada BIG, USGS, dan Kementerian Pekerjaan Umum yang telah menyediakan data secara terbuka untuk penelitian ini.

\section{DAFTAR PUSTAKA}

Alaska Seismic Hazards Safety Commission (2018), 2018 M7.1 Anchorage, Alaska Earthquake Alaska Seismic Hazards Safety Commission, Diambil dari https://seismic.alaska.gov/download/ashsc_meeting s_minutes/sig_eq_2018_Anchorage_final_update_12 0619.pdf.

Bhatt, N., Pancholi, V., Chopra, S., Rout, M.M., Shah, R.D. dan Kothyari, G.Ch. (2019), "Rapid Seismic Hazard Assessment of The Sabarmati River Basin in Gujarat State, Western India Using GIS Techniques", Bulletin of Engineering Geology and the Environment, Vol.78, No.6, hal. 3927-3942.
BMKG (2018), BMKG Ungkap Kronologi Tsunami Selat Sunda. Diambil dari https://www.bmkg.go.id/berita/?p=bmkg-ungkapkronologi-tsunami-selat-sunda\&tag=\&lang=ID.

BNPB (2008), Peraturan Kepala Badan Nasional Penganggulangan Bencana No. 4 Tahun 2008 tentang Pedoman Penyusunan Rencana Penanggulangan Bencana BNPB,.

BNPB (2020), Data dan Informasi Bencana Indonesia BNPB, Diambil dari http://dibi.bnpb.go.id/.

BNPB (2015), Petunjuk Teknis Penyusunan Peta Ancaman dan Rlsiko Bencana untuk Tingkat Kabupaten/Kota, 2 Ed., BNPB, Jakarta.

Daryono (2019), Sesar Aktif Picu Gempa di Majalengka, Cirebon, dan Kuningan. Diambil dari https://kumparan.com/daryono-bmkg/sesar-aktifpicu-gempa-di-majalengka-cirebon-dan-kuningan1rLOqtzoOoK.

Daryono, D., Brotopuspito, K.S. dan Sutikno, S. (2018), "Hubungan Antara Indeks Kerentanan Seismik Dan Rasio Kerusakan Pada Satuan Bentuklahan Di Zona Graben Bantul Yogyakarta", PROCEEDING, SEMINAR NASIONAL KEBUMIAN KE-11 PERSPEKTIF ILMU KEBUMIAN DALAM KAJIAN BENCANA GEOLOGI DI INDONESIA 5 - 6 SEPTEMBER 2018, Diambil dari https://repository.ugm.ac.id/274873/.

Deny, S. (2020), Ada Tol, Waktu Tempuh dari Bandung ke Bandara Kertajati Bakal Lebih Cepat. Diambil dari https://www.liputan6.com/bisnis/read/4350316/ada -tol-waktu-tempuh-dari-bandung-ke-bandarakertajati-bakal-lebih-cepat.

Departemen Pekerjaan Umum Direktorat Jendral Penataan Ruang (2007), Peraturan Menteri Pekerjaan Umum No. 21/PRT/M/2007 tentang Pedoman Penataan Ruang Kawasan Rawan Letusan Gunung Berapi dan Kawasa Rawan Gempa Bumi Departemen Pekerjaan Umum Direktorat Jendral Penataan Ruang, Diambil dari https://pustaka.pu.go.id/biblio/pedoman-penataanruang-kawasan-rawan-letusan-gunung-berapi-dankawasan-rawan-gempa-bumi-peraturan-menteripekerjaan-umum-no-21-prt-m-2007/ED882.

D’Oro, R. dan Thiessen, M. (2018), Strict Building Codes Helped Anchorage Withstand Quake. Diambil dari https://apnews.com/article/anchorage-northamerica-us-news-ap-top-news-earthquakes018a78f7cfb646b8a6653766a953cacd.

Jati, R. dan Amri, Mohd.R. (2016), Risiko Bencana Indonesia, BNPB, Jakarta. 
Kementerian Keuangan Republik Indonesia (2019), "Siap Tanggap Hadapi Bencana", Media Keuangan, Vol.14, No.137, hal. 17-26.

Kementerian Pekerjaan Umum dan Perumahan Rakyat (2018), Kajian Rangkaian Gempa Lombok Provinsi Nusa Tenggara Barat, Kementerian Pekerjaan Umum dan Perumahan Rakyat.

Kumar, A., Baro, O. dan Harinarayan, N.H. (2016), "Obtaining the Surface PGA from Site Response Analyses Based on Globally Recorded Ground Motions and Matching with the Codal Values", Natural Hazards, Vol.81, No.1, hal. 543-572. http://doi.org/10.1007/s11069-015-2095-x.

León, J. dan March, A. (2017), "Taking Responsibility for 'Shared Responsibility': Urban Planning for Disaster Risk Reduction Across Different Phases. Examining Bushfire Evacuation in Victoria, Australia", International Planning Studies, Vol.22, No.3, hal. 289304.

http://doi.org/10.1080/13563475.2016.1234368.

Menteri Dalam Negeri Republik Indonesia (2021), Instruksi Menteri Dalam Negeri Nomor 15 Tahun 2021 tentang Pemberlakuan Pembatasan Kegiatan Masyarakat Darurat Corona Virus Disesase 2019 di Wilayah Jawa dan Bali. Kementerian Dalam Negeri Republik Indonesia, Diambil dari https://covid19.go.id/storage/app/media/Regulasi/2 021/Juli/INMENDAGRI\%20NO\%2015\%20TAHUN\%20 2021\%20TENTANG\%20PPKM\%20DARURAT.pdf.

Presiden Republik Indonesia (2007a), Undang-Undang No. 26 Tahun 2007 Tentang Penataan Ruang. Presiden Republik Indonesia,.

Presiden Republik Indonesia (2007b), Undang-Undang No. 24 Tahun 2007 Tentang Penanggulangan Bencana Presiden Republik Indonesia,.

Presiden Republik Indonesia (2020), Keputusan Presiden No. 12 Tahun 2020 Tentang Penetapan Bencana Nonalam Penyebaran Corona Virus Disease 2019 sebagai Bencana Nasional Presiden Republik Indonesia, Diambil dari https://peraturan.bpk.go.id/Home/Details/135718/k eppres-no-12-tahun-2020.

Pusat Studi Gempa Nasional (2017), Peta Sumber dan Bahaya Gempa Indonesia Tahun 2017,.

Ramadhan, V. dan Wijaya, S. (2020), "Alternatif Sumbangan Penanggulangan Bencana Sebagai Pengurang Penghasilan Bruto (Studi Kasus Gempa Lombok)", Jurnal Pajak dan Keuangan Negara (PKN), Vol.2, No.1, hal. 46-56. http://doi.org/10.31092/jurnal.
Rochman, B.T.F., Meilina, C., Fajriati, C.E., Amalia, D.N. dan Subhan, H. (2021), "Analisis Ekologi Administrasi: Dampak Pembangunan Bandara Internasional Jawa Barat (BJIB) Kertajati Di Desa Putridalem Kecamatan Jatitujuh Kabupaten Majalengka", Jurnal Inovasi Penelitian, Vol.1, No.12, hal. 2761-2768. http://doi.org/10.47492/jip.v1i12.539.

Sjafrizal, Abdullah, F., Ismail, N. dan Hermansyah, L.V. (2017), "Analisis Rencana Tata Ruang Wilayah (RTRW) Kota Sabang Berdasarkan Peta Jalur Patahan Aktif Di Kota Sabang", Jurnal Ilmu Kebencanaan: Program Pascasarjana Unsyiah, Vol.4, No.1. Diambil dari http://jurnal.unsyiah.ac.id/JIKA/article/view/13311.

Susilanto, P., Ngadmanto, D., Sunardi, B. dan Rohadi, S. (2019), "Analisis Kecepatan Gelombang Geser (Vs) Sebagai Upaya Mitigasi Bencana Gempabumi Di Kulonprogo, DIY", Jurnal Lingkungan dan Bencana Geologi, Vol.10, No.2. http://doi.org/10.34126/jlbg.v10i2.215.

Tehseen, R., Farooq, M.S. dan Abid, A. (2020), "Earthquake Prediction Using Expert Systems: A Systematic Mapping Study", Sustainability, Vol.12, No.6, hal. 2420. http://doi.org/10.3390/su12062420.

Tohari, A. dan Wardhana, D.D. (2018), "Mikrozonasi Seismik Wilayah Kota Padang Berdasarkan Pengukuran Mikrotremor", RISET Geologi dan Pertambangan, Vol.28, No.2, hal. 205-220. http://doi.org/10.14203/risetgeotam2018.v28.984.

Widyawarman, D. dan Fauzi, E.R. (2020), "Aplikasi Mikrotremor Untuk Mikrozonasi Tingkat Potensi Bencana Gempa Bumi Di Kampus I Universitas PGRI Yogyakarta", Jurnal Geosaintek, Vol.6, No.2, hal. 8796. http://doi.org/10.12962/j25023659.v6i2.6778.

Yuliatmoko, R.S., Kurniawan, T., Hardy, T. dan Perdana, Y.H. (2020), "Kerentanan Goncangan Tanah pada Sedimen Permukaan Wilayah Kecamatan Tarogong Kaler, Tarogong Kidul, Garut Kota, dan Karang Pawitan, Kabupaten Garut berdasarkan Analisa Data Mikrotremor", Jurnal Lingkungan dan Bencana Geologi, Vol.11, No.1, hal. 11-23. http://doi.org/10.34126/jlbg.v11i1.280. 